\title{
Chemical composition of rosemary (Rosmarinus officinalis L.) leaves under salt stress
}

\author{
Bibi Sadia $^{1 *}$, Shazia Irfan ${ }^{1}$ and Zahoor Ahmed Bazai ${ }^{2}$ \\ 1. Department of Botany, Sardar Bahadur Khan Women's University Quetta, Pakistan \\ 2. Department of Botany, University of Balochistan, Pakistan \\ *Corresponding author's email: zarmal.gul@gmail.com \\ Citation \\ Bibi Sadia, Shazia Irfan and Zahoor Ahmed Bazai. Chemical composition of rosemary (Rosmarinus officinalis L.) leaves \\ under salt stress. Pure and Applied Biology. Vol. Issue 2, 2016, pp355-360. http://dx.doi.org/10.19045/bspab.2016.50046
}

Received: $15 / 12 / 2015$

Revised: $24 / 03 / 2016$

Accepted: 04/04/2016

Online First: 18/0042016

\section{Abstract}

Rosmarinus officinalis L. is an important plant due to its chemical constituents, medicinal properties and commercial use. The present study was carried out to determine the change in concentration of chemicals in salt stressed $R$. officinalis. Plants were treated with 50,100 and $150 \mathrm{mM} \mathrm{NaCl}$ to determine the change in moisture content level and concentrations of carbohydrates, alkaloids, flavonoids and phenols. Results revealed that moisture content and carbohydrates decreased with increased salinity. Maximum values of moisture content $(60.39 \%)$, insoluble carbohydrates $(2.25 \mathrm{~g})$ and soluble carbohydrates $(24.5 \mathrm{ml})$, found in control treatment, while the minimum values of moisture content (48\%) and $1.47 \mathrm{~g}$ and $21 \mathrm{ml}$ for insoluble and soluble carbohydrates respectively were recorded for $150 \mathrm{mM} \mathrm{NaCl}$ treatment. Maximum values for alkaloids $0.9 \mathrm{~g}$ and flavonoids $0.82 \mathrm{~g}$ were recorded for $50 \mathrm{mM} \mathrm{NaCl}$ treatment while minimum values, alkaloids $0.76 \mathrm{~g}$ and flavonoids $0.32 \mathrm{~g}$ were recorded for $150 \mathrm{mM} \mathrm{NaCl}$ treatment. Quantitative analysis of phenols expressed that phenols increased with increased salinity i.e for control lowest $3.02 \%$ and for $150 \mathrm{mM} \mathrm{NaCl}$ highest value $4.24 \%$ obtained. It concluded that phenols might release the oxidative stress caused by $\mathrm{NaCl}$ applications but their increase is also beneficial because they are natural antioxidants.

Key words: Rosemary; Salt Stress; Concentration; NaCl; Quantitative analysis.

\section{Introduction}

Salinity is now becoming threatens environmental issue and its adverse effects are more on agriculture [1]. As more than $25 \%$ of the total area of the terrestrial land is saline also the fresh water supply is becoming a major problem and $97 \%$ water is saline, this necessitates investigation into use of saline areas for agricultural cultivation as salinity causes changes in plant growth, resistance to environmental conditions and yield of carbohydrates, protein and fatty acids as well as proline and phenols [2]. It was found that salt stressed plants had higher concentrations of phenolic compounds and antioxidants, but lower levels of photosynthetic pigments [3]. In Rosmarinus officinalis salt stress decreased leaf water content but increased oxidative stress [4].

Rosmarinus officinalis commonly known as rosemary has important chemical constituents, like alkaloids, flavanoids, phenols, rosmarinic acid, mineral 
constituents, vitamin A, C and others [5]. Its main importance is due to its antioxidant property given by antioxidants i.e phenols. Phenols are natural antioxidants. Antioxidants are the compounds that finish or reduce the oxidative stress. Oxidative stress in organisms is very dangerous because it cause tumors of different kinds. It has a number of uses as a fragrance in perfume and seasonings. From medicinal point of view it is used to strengthen the circulatory system and nerves system. Furthermore it is use to control cancer, and regulate blood pressure etc [5]. The aim of the study was to investigate the change in chemical constituents that is moisture content, carbohydrates (soluble and insoluble) alkaloids, flavonoids and phenols in salt stressed rosemary plants. This was done in order to determine the cultivation of Rosmarinus officinalis under saline conditions.

\section{Materials and methods}

\section{Sample collection}

One-Year old rosemary $(n=24)$ plants were randomly selected from botanical garden of SBK Women's University Quetta (Pakistan). These selected plants were treated with different molarities of $\mathrm{NaCl}$ from May to August 2012. Arranged these 24 plants in Randomized Complete Block Design in 4-plots, with three replications. Treatments included, Control (no treatment, $2 \mathrm{~L}$ water per plant per week), 2 L $50 \mathrm{mM}$ $\mathrm{NaCl}$ per plant per week, $2 \mathrm{~L} 100 \mathrm{mM} \mathrm{NaCl}$ per plant per week and $2 \mathrm{~L} 150 \mathrm{mM} \mathrm{NaCl}$ per plant per week.

\section{Sample preparation}

For the determination of moisture content fresh leaves were taken. For all other quantitative tests air dried leaves (grounded to a fine powder using an electrical grinder) were used.

Methods used for quantitative analysis of chemicals
Moisture content was determined by the AOAC (2003) method, used by Gul \& Safdar, (2009) [6]. Determination of carbohydrates concentration was performed using the method described by Ali et al., (2003) [7]. Alkaloids were quantified by the method of Okwu \& Josiah, (2006) [8]. The concentrations of flavonoids and phenols were determined by using the methods used by Edeoga et al., (2005) [9].

\section{Statistical analysis}

Statistical analysis was carried out to find whether the different treatments (salt stress levels) have significant (different) or nonsignificant effects on the concentration of investigated chemicals. For this purpose standard error bars were added to the graphs after calculating the standard error of the means for each quantitatively analyzed chemical. The bars are also helpful in finding that how much uncertainty there is in the data [10].

\section{Results}

Highest moisture content $60.39 \%$, was noted in control treatment followed by the $50 \mathrm{mM}$ $\mathrm{NaCl}$ treatment (57.64\%). The lower moisture content $48 \%$ was found in $150 \mathrm{mM}$ $\mathrm{NaCl}$ treatment (Figure-1). Highest carbohydrates amount of insoluble sugars (polysaccharides) $2.25 \mathrm{~g}$ and soluble sugars (monosaccharides and disaccharides) 24.5 $\mathrm{ml}$ were determined from controlled plot (Figure-2 \& 3). Maximum amount of alkaloids was $0.9 \mathrm{~g}$ calculated for the 50 $\mathrm{mM} \mathrm{NaCl}$ plot. The results showed that alkaloids increased at $50 \mathrm{mM} \mathrm{NaCl}$ salinity, they also increased up to some extent at 100 $\mathrm{mM} \mathrm{NaCl}$ treatment, but when salinity increased up to $150 \mathrm{mM} \mathrm{NaCl}$, the alkaloids amount became lower than that of control one (Figure-4). The result for flavonoids was same as that for alkaloids. The $50 \mathrm{mM}$ $\mathrm{NaCl}$ treated plants were have highest amount $0.82 \mathrm{~g}$, while $150 \mathrm{mM} \mathrm{NaCl}$ treated rosemary plants have lowest amount $0.32 \mathrm{~g}$ of flavonoids (Figure-5). Increased salinity 
caused increase in phenol concentration, highest phenol $4.24 \%$ found in $150 \mathrm{mM}$ $\mathrm{NaCl}$ while the lowest phenol $3.02 \%$ was found in Control (Figure-6).

Overlap standard error bars demonstrate that the two treatments on average do not cause different effects while the non-overlap bars revealed that two treatments have different effects. Error bars of moisture content indicated that $150 \mathrm{mM} \mathrm{NaCl}$ salinity treatment have entirely different effect (Figure-1). In case of polysaccharides two treatments (50 and $100 \mathrm{mM} \mathrm{NaCl}$ ) denoted non-significant results while control and 150 $\mathrm{mM} \mathrm{NaCl}$ treatments showed significant effects. All the treatments produced significant effects in case of mono and disaccharides (Figure-2 \& 3). For alkaloids highest salinity treatment $(150 \mathrm{mM} \mathrm{NaCl})$ expressed significant results (Figure-4). Significant results were obtained for flavonoids at $50 \mathrm{mM} \mathrm{NaCl}$ treatment (figure-5). In case of phenols all salinity treatments $(50,100$ and $150 \mathrm{mM} \mathrm{NaCl})$ produced significant effects as compared to control (Figure-6). Lengths of error bars show the concentration of means over the area. For almost all the treatments in all investigated chemicals, the obtained bars were of short length, indicated that the means were not so dispersed rather they were concentrated over the small area.

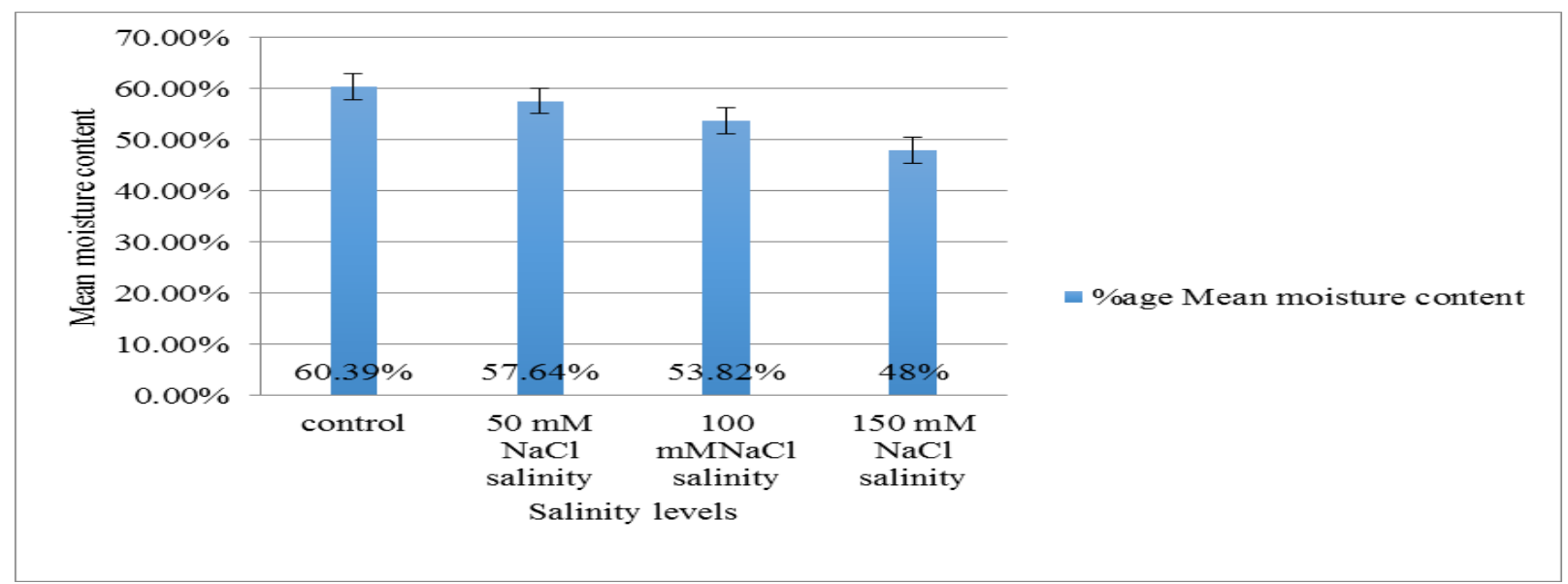

Figure 1. Moisture content (mean with \pm standard error bars "I")

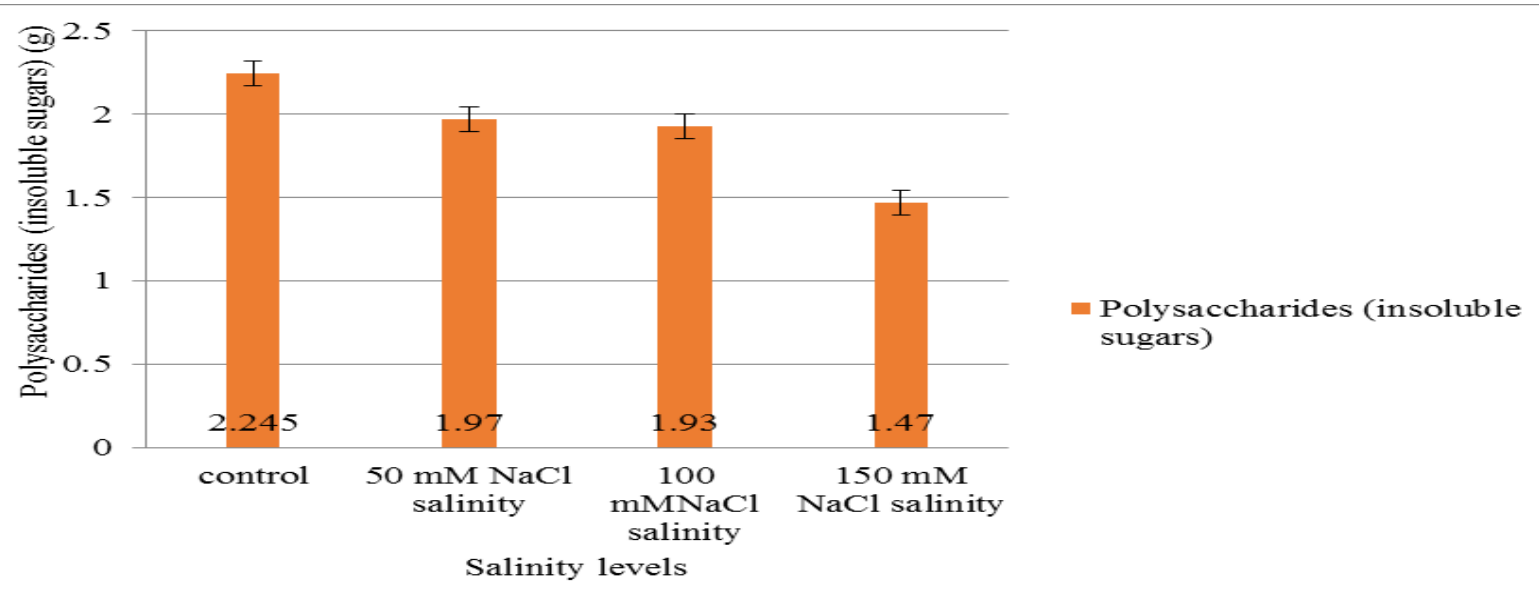

Figure 2. Polysaccharides (mean with \pm standard error bars "I") 


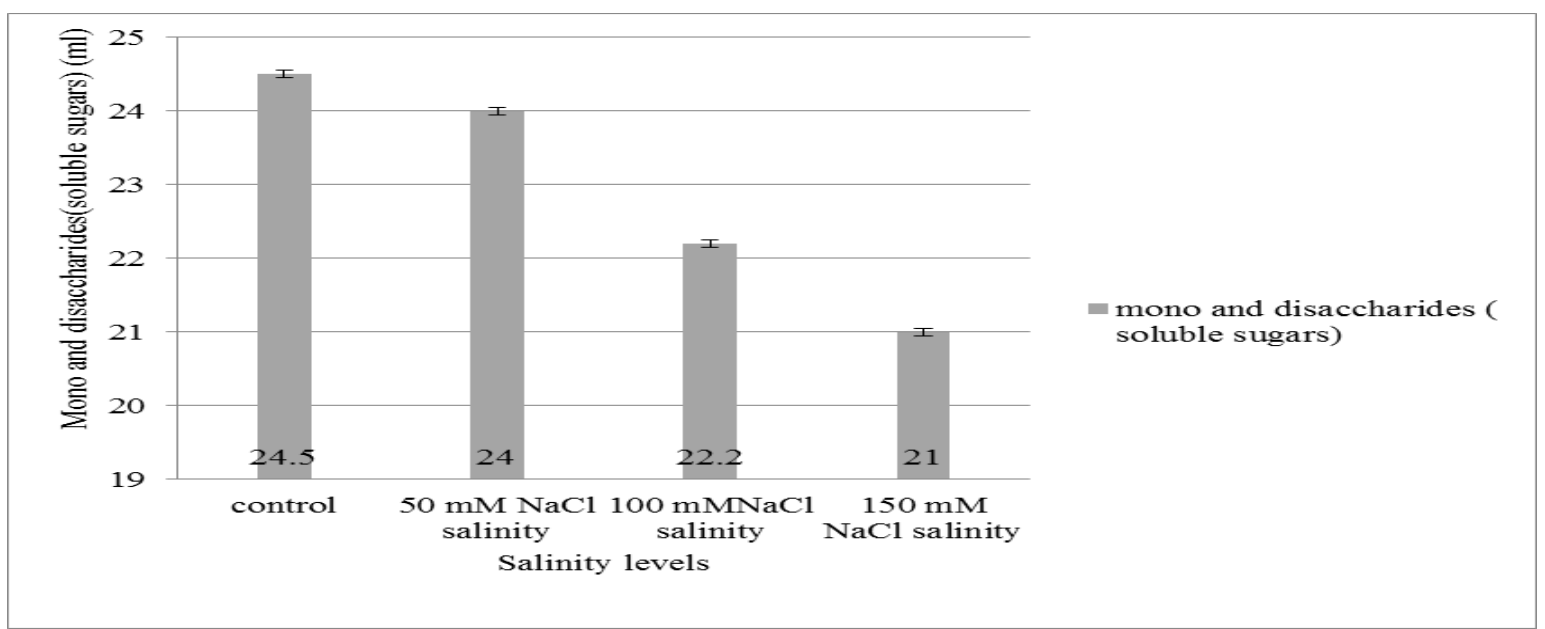

Figure 3. Monosaccharides and disaccharides (mean with \pm standard error bars "I")

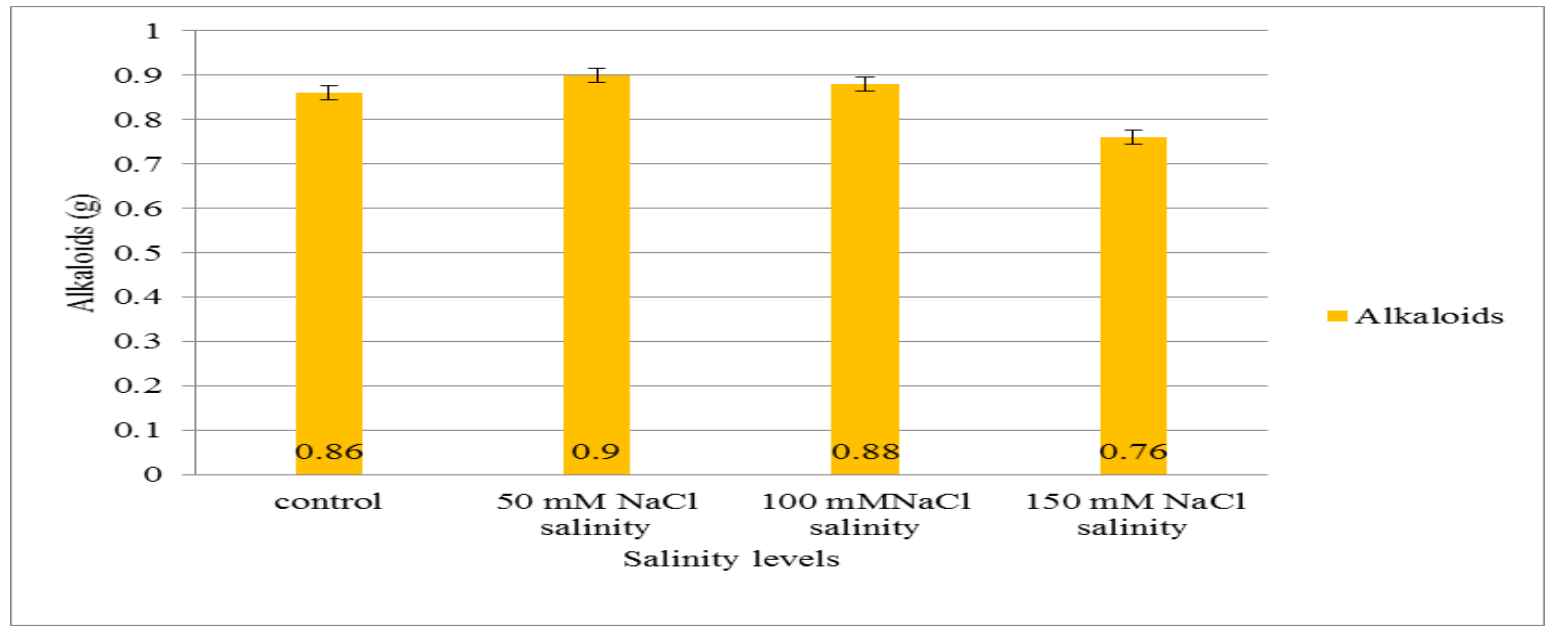

Figure 4. Alkaloids (mean with \pm standard error bars "I")

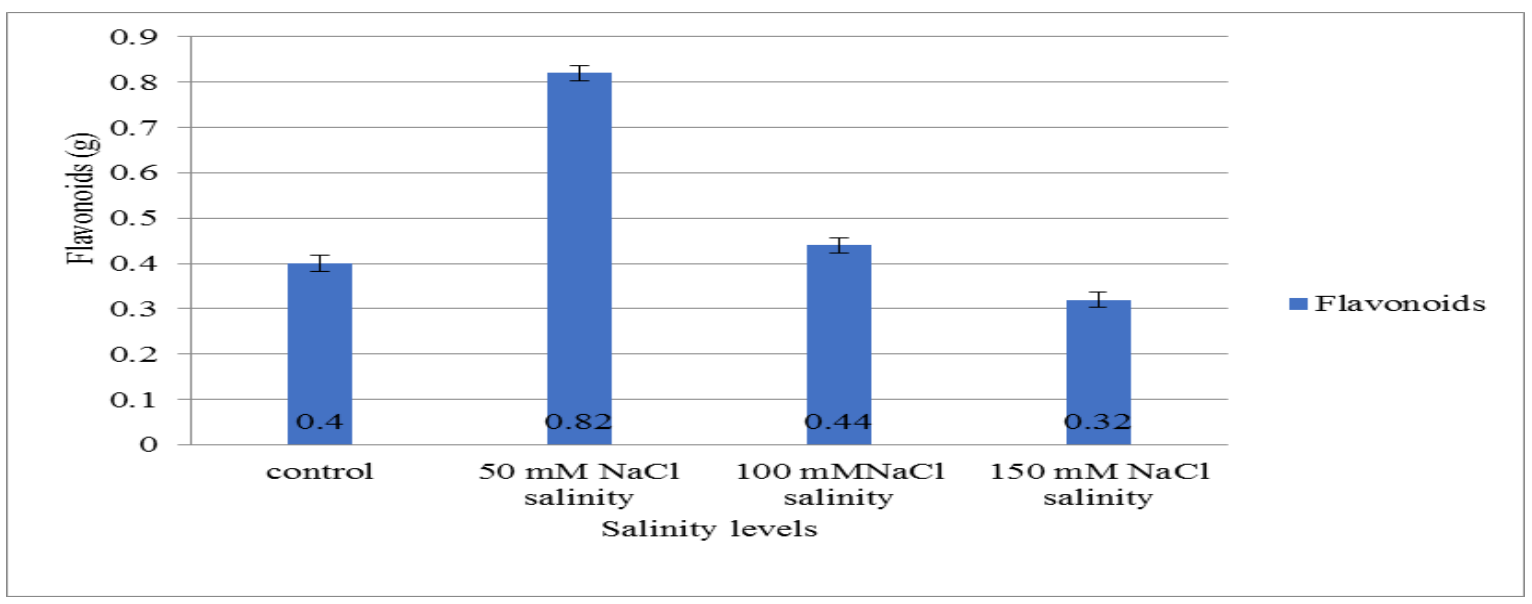

Figure 5. Flavonoids (mean with \pm standard error bars " $I$ ") 


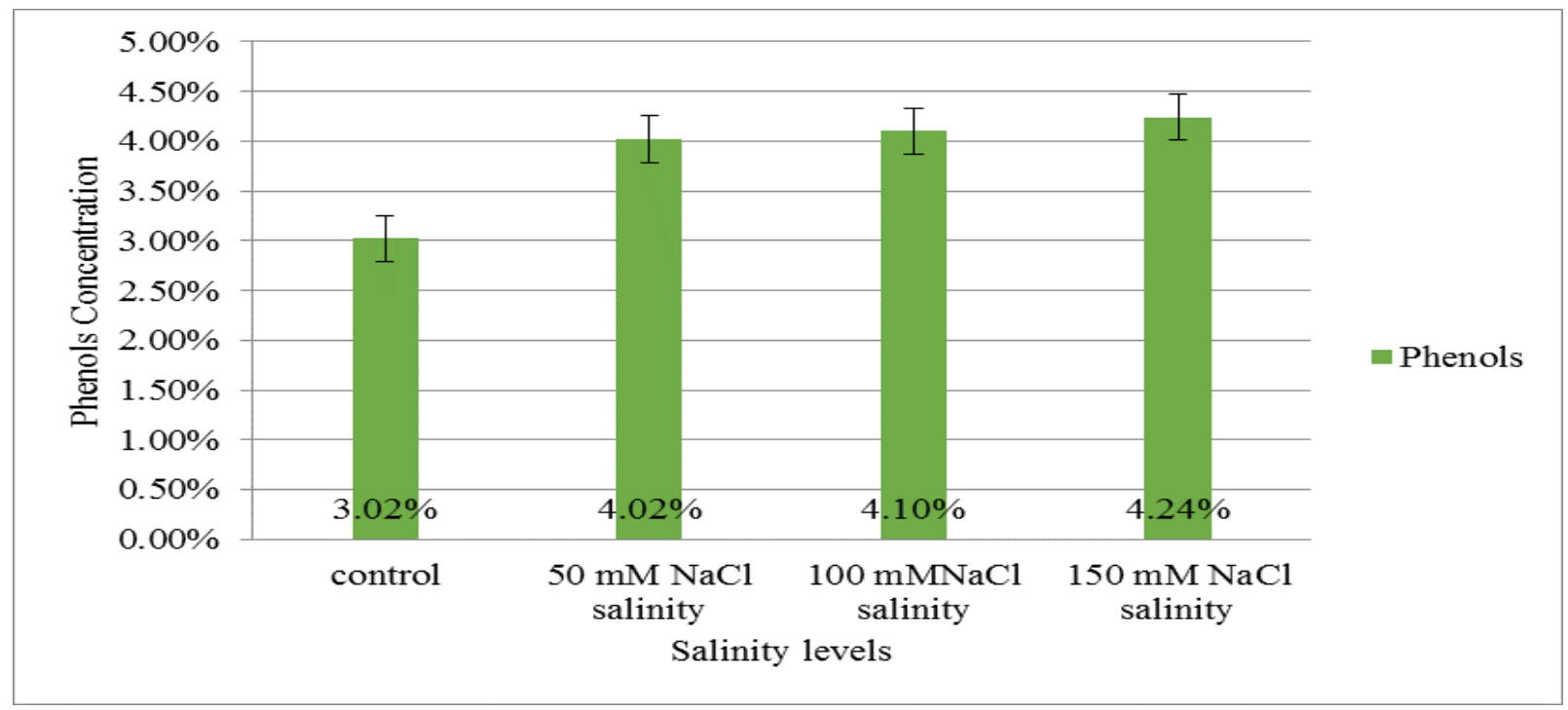

Figure 6. Phenols (mean with \pm standard error bars "I")

\section{Discussion}

A comparative analysis showed that moisture content decreased with increased salinity levels, similar results [11] on Thai jasmine rice and Rosmarinus officinalis were obtained. High salinity resulted high osmotic pressure which restricted plant cells to uptake water so decreased moisture content may be due to defect metabolism in plant cells [12]. Results showed that carbohydrates decreased with increased salinity levels, results were similar with studies [13] on Datura stramonium and Salvia officinalis. Decreased moisture content might reduce photosynthetic activity which in turn resulted decreased carbohydrates level.

Salinity caused to increase the total alkaloids, similar results reported by Ali, [14]. But the alkaloids only highly increased at $50 \mathrm{mM} \mathrm{NaCl}$ salinity, also increased to some extent at $100 \mathrm{mM}$ salinity but decreased at $150 \mathrm{mM}$ salinity as compared to control one. Quantitative evaluation of flavonoids showed the same results like that for alkaloids. Highest found in $50 \mathrm{mM} \mathrm{NaCl}$ level and lowest calculated from $150 \mathrm{mM}$
$\mathrm{NaCl}$ treatment. Flavonoids increased when salinity applied from $50 \mathrm{mM}$ to below 100 $\mathrm{mM}$. Phenols increased with increased salinity levels and results similar with the results of Mehrizi et al., [15] and Abd - EL - Azim et al., [16] they investigated the effect of salts on Achillea fragratissima, Rosmarinus officinalis. Reduction in growth may have resulted in a new pattern of providing additional carbon skeleton for phenols indicating that salinity is more effective factor in increasing phenols, the natural antioxidants [17]. The study indicated that that rosemary can tolerate moderate applications of salinity. The increasing salinity caused increase in oxidative stress, and it may be a mechanism for protecting plants from salt stress rather than causing damage to plants.

\section{Conclusion}

Rosemary presents efficient mechanism for tolerating salinity. The moisture content and carbohydrates were decreased with the increased salinity. The alkaloids and flavonoids were highest at $50 \mathrm{mM} \mathrm{NaCl}$ salinity but decreased at higher salinity. On the other hand phenols increased when 
salinity levels were raised. This increase of phenol may be due to release the oxidative stress caused by the applied salinity, because the phenols of rosemary have good antioxidant role. The findings suggested that rosemary can be cultivated under specific salinity for production of phenols (antioxidants), alkaloids and flavonoids.

\section{Authors' contributions}

Conceived and designed the experiments: $S$ Irfan, Performed the experiments: B Sadia, Analyzed the data: B Sadia, Contributed reagents/materials/analysis tools: $S$ Irfan \& B Sadia, Wrote the paper: B Sadia \& S Irfan.

\section{References}

1. Yan S, Tang Z, Su W \& Sun W (2005). Proteomic analysis of salt stress-responsive proteins in rice root. Proteomics 5(1): 235244.

2. Said-Al Ahl HAH \& Omer EA (2011). Medicinal and aromatic plants production under salt stress. A review. Herba Pol 57(1): 72-87.

3. Kiarostami Kh, Mohseni R \& Saboora A (2010). Biochemical changes of Rosemarinus officinalis L. under salt stress. $J$ Stress Physiol Biochem 6(3): 114-122.

4. Tounekti T, Vadel AM, Onate M, Khemira H \& Bosch SM (2011). Salt induced oxidative stress in rosemary plants: Damage or protection? Environ Exp Bot 71: 298-305.

5. Tsai PJ, Tsai TH \& Ho SC (2007). Invitro inhibitory effects of rosemary extracts on growth and glucosyltransferase activity of Streptococcus sobrinus. Food Chem 105: 311-316.

6. Gul S \& Safdar M (2009). Proximate composition and mineral analysis of Cinnamon. Pak J Nutr 8(9): 1456-1460.

7. Ali AA, Fahmi HS, Khadr FG \& Desoki RM (2003). Changes in growth, pigments and carbohydrates of Soybean and Rosemary Agroecosystem in response to soils treated with ceramic dust in Egypt. J Biol Sci 3(9): 802-823.
8. Okwu DE \& Josiah C (2006). Evaluation of the chemical composition of two Nigerian medicinal plants. Afr J Biotechnol 5(4): 357361.

9. Edeoga HO, Okwu DE \& Mbaebie BO (2005). Phytochemical constituents of some Nigerian medicinal plants. Afr J Biotechnol 4(7): 685-688.

10. Cumming G, Fidler F \& Vaux DL (2007). Error bars in experimental biology. $\mathrm{J}$ Cell Biol 177(1): 7-11.

11. Summart J, Thanonkeo P, Panichajakul S, Prathepha P \& McManus MT (2010). Effect of salt stress on growth, inorganic ion and proline accumulation in Thai aromatic rice, Khao Dawk Mali 105, callus culture. Afr J Biotechnol 9(2): 145-152.

12. Cicek N \& Cakirlar H (2002). The effect of salinity on some physiological parameters in two maize cultivars. Bulg $J$ Plant Physiol 28(1-2): 66-74.

13. Hendawy SF \& Khalid KhA (2005). Response of sage (Salvia officinalis L.) plants to zinc application under different salinity levels. J Appl Sci Res 1(2): 147155.

14. Ali RM (1991). Changes in chemical composition of fruits of salanized Datura stramonium. J Islamic Acad Sci 4(4): 289292.

15. Mehrizi MH, Shariatmadari $H$, Khoshgoftarmanesh AH \& Dehghani F (2012). Copper effects on growth, lipid peroxidation, and total phenolic content of Rosemary leaves under salinity stress. $J$ Agr Sci Tech 14: 205-212.

16. Abd - EL - Azim WM \& Ahmed STn (2009). Effect of salinity and cutting date on growth and chemical constituents of Achillea fragratissima Forssk, under Ras sudr conditions. Res J Agric Biol Sci 5(6): 1121-1129.

17. Dicko MH, Gruppen H, Traoré AS, Voragen AG \& van Berkel WJ (2006). Review: Phenolic compounds and related enzymes as determinants of sorghum for food use. Biotechnol and Mol Biol Rev 1: 21-38. 